\title{
Fraud Detection, Conservatism and Political Economy of Whistle Blowing
}

\author{
Ozili Peterson, $\mathrm{K}$. \\ University of Essex, Colchester, United Kingdom \\ Email: pozili@essex.ac.uk.
}

\section{Doi:10.5901/ajis.2016.v5n3p17}

\begin{abstract}
This paper presents a discussion on whistle-blowing and take the view that whistle-blowing is an important fraud detection technique. A discussion of some factors that influence the whistle-blowers' incentive to blow the whistle or to remain silent in the face of persuasive fraud red flags, is also presented. The paper suggests that the tradeoff between the cost and benefit of whistle-blowing may compel the whistle-blower to apply some degree of conservatism in their whistle-blowing activities. Also, some discussion on how whistle-blowing might be influenced by firm-level politics, country-level political economy, firm ownership and other institutional factors is presented. Finally, although the provision of incentives can increase the appeal to encourage whistle-blowing, the appeal to blow the whistle may be weakened when the whistle-blower takes into account the larger context that influence the decision to blow the whistle or to remain silent.
\end{abstract}

Keywords: Forensic Accounting, Fraud Detection, Whistle Blowing, Politics, Conservatism, Ownership Control, Political Economy.

\section{Introduction}

The purpose of this paper is to provide a discussion on whistle-blowing. The paper discuss some factors that influence the potential whistle-blower's incentive to blow the whistle or to remain silent in the face of persuasive fraud red flags. After persuasive red flags of fraud have been identified in firms' financial and non-financial records through the help of forensic accounting techniques and the expertise of forensic investigators, it can be difficult sometimes to associate fraud red flags with a personality behind the fraud in the sense that there is a human agent behind every fraudulent behavior. This difficulty in recent times has led to the need for whistle-blowers to emerge to support on-going fraud investigation activities.

Researchers and professionals, alike, identify whistle-blowers as the most important source of fraud detection (ACFE, 2016). Regulators and firms can save substantial resources that would go into fraud investigation if whistleblowers emerge early enough and quite often. However, whistle-blowing brings some benefits and costs to the whistleblower, and potential whistle-blowers may consider the cost and benefit of whistle-blowing before doing so, and will also face the choice of whether to remain silent or to blow the whistle. In this paper, we suggest that the cost-benefit trade-off might motivate whistle-blowers to apply greater (or less) conservatism in whistle-blowing. Also, this paper discuss the influence of some institutional factors, politics, political economy and firm ownership structure on whistle-blowers' incentive to blow the whistle or to remain silent. We make some propositions and conclude that certain firm-level, political and institutional factors can influence a whistle-blower's incentive to expose fraud.

Forensic accounting practices or activities can aid any fraud detection activity where records of financial and nonfinancial contractual transactions between two or more parties are kept. After persuasive red flags of fraud have been identified through the use forensic accounting techniques as well as the expertise of forensic investigators, the next step is to associate fraud red flags with a personality in the sense that there is a human agent behind a fraudulent behavior (Ozili, 2015). Forensic accounting fails at this point because, at best, forensic accounting techniques can help forensic investigators trace fraud to one or more units or departments in an organization responsible for specific roles but it may not expose the personality behind fraud. While forensic accounting-based fraud detection techniques on its own may not effectively identify fraud perpetrators simply by tracing red flags of fraud, whistle-blowing is more effective to find a personality behind fraudulent behaviour.

Also, there is often a good case to employ word-of-mouth confessions and testimonials before a court of law as techniques to detect fraud. However, word-of-mouth confessions and testimonials have some demerits. The main drawback is that it can give rise to conflicting truths even when the truth is obvious which then complicates the fraud detection process. For instance, speaking to the accountant: did you know that the bank manger gave loans to ghost 
borrowers? Did you know about the cover-up and when did you know it? This kind of questions require the accountant to admit that the bank has ghost borrowers, and that the accountant knew that loan was borrowed to ghost borrowers, and that the accountant is fully aware of this behavior when in fact the accountant may not be aware of any ghost borrower. This kind of situation creates an ethical dilemma for people testifying in fraud cases because they do not want to implicate themselves. To avoid this kind of complications during a fraud detection process, this paper takes the view that whistleblowing saves time, cost and resources that would have been channeled to fraud investigation using traditional fraud detection techniques. While there are moral justifications to rationalize the need for whistle-blowing as a better fraud detection and/or deterrent of fraudulent behavior, this study also highlights some issues associated with whistle-blowing activities, precisely, institutional and political economy influences - an issue that has not been discussed in prior study. The methodology we adopt in this paper is a systematic review of the extant literature on whistle-blowing.

Finally, this paper contributes to the whistle-blowing literature by applying ideas from politics and political economy to examine the impact of politics on whistle-blowing. By applying a political economy approach, first, we can gain some insights to understand why whistle-blowing may be problematic and filled with nervous feelings rather than encouraging individuals and employees to boldly blow the whistle to expose fraud perpetrators. Two, it can help us to understand why some countries have more number of recorded whistle-blowers while other countries have fewer or no recorded whistleblowers. Three, political economy approach can give us some clue as to when and why one can expect the trend in whistle-blowing to change over time.

The remainder of this paper is organized as follows. Section 2 presents the conceptual framework on whistleblowing. Section 3 discuss some motivations for whistle-blowing. Section 4 presents some discussion on conservative whistle-blowing, and institutional influence on conservative whistle-blowing. Section 5 discuss the influence of politics on whistle-blowing. Section 6 provides some discussion on firm ownership. Section 7 concludes.

\section{Whistleblowing: Conceptual Framework}

\subsection{Conceptual Framework}

When certain individuals have knowledge of the truth and feel they have a moral obligation to undo falsehood whether it is deliberate or accidental, such individuals will report such falsehood. In this sense, such individuals are referred to as 'whistle-blowers'. Simply put, whistle-blowing refers to: calling attention to fraud or concealed information when such information is harmful to the welfare of others (Westin, 1982). Whistle-blowing is the disclosure of "illegal, immoral, or illegitimate practices to persons or organizations that may be able to effect action." (Near and Miceli, 1988: p.5). The recipient of whistle-blowing are either internal parties in the organization (for example, internal auditors) ${ }^{1}$ or external parties (for example, industry regulators, courts of law, etc.); therefore, whistle-blowers can choose to report fraud to internal or external parties or both. With respect to an organization and its environment, whistle-blowers may be internal (i.e., members of the organization) or external to the organization. Internal whistle-blowers are usually more aware of, and are affected by fraudulent and unethical behavior of the organization but may be more afraid of the consequences of blowing the whistle, particularly, the loss of job. On the other hand, whistle-blowers may be external to an organization. External whistle-blowers do not face serious consequences or fear for blowing the whistle; however, external whistleblowers often may not be aware of the extent of unethical/fraudulent behavior in the organization because they are external to the organization (Read and Rama, 2003). Moreover, four conditions needs to be fulfilled for an individual to be termed a whistle-blower. The individual (i) must be a member of an organization or be part of a system that intentionally or unintentionally allow/permit a fraud culture or unethical behavior to go unchecked (ii) must be in a position where they are privy to private information, e.g., financial and non-financial records of the firm (iii) must have strong motivation to expose fraudulent and/or unethical behavior or practices; and (iv) report such behavior to the relevant authority or to the general public through media sources if the whistle-blower has reasons to believe that the relevant authority will ignore the claims made to it. 


\section{Motivations to Blow or Not to Blow the Whistle}

Why Do Individuals/Employees Blow the Whistle? The motivation for individuals and firms to blow the whistle against fraud are diverse. Individuals may blow the whistle because of their personality traits, religiosity, ideology, cultural and societal values, etc., the list is not exhaustive. The propensity to blow the whistle against fraud red flags is common among individuals with strong value orientation and personality traits (Park et al, 2014), strong moral reasoning (Liyanarachchi and Newdick, 2009), high religiosity and ethical ideology (Barnett et al, 1996), strong dissatisfaction with injustice, power distance, gender inequality and gender gap (Curtis et al, 2012), etc. Other motivations to blow the whistle against fraudulent/unethical behavior are related to workplace issues. For example, the unfair treatment of employees from diverse backgrounds is one example. Employees that feel they are not treated with fairness are more likely to blow the whistle when they detect fraudulent practices that have a direct impact on the fairness they deserve. In some cases, employees may blow the whistle as payback or revenge in response to events in the workplace. To illustrate, a good example in this case are employees that blow the whistle against the unethical behavior of the line manager as revenge for not giving them (the employees) the promotion they deserve. Employees may deliberately report the line manager to a top management member that do not have a good relationship with the line manager. Also, employees may blow the whistle against an organization when the activities of the organization switch from being legal (and ethical) to illegal (and unethical). While the motivation to blow the whistle vary depending on the context, the pressure for employees to blow the whistle is strongest when there is strong organizational support ${ }^{2}$ for whistle-blowers, and also when the whistle-blower knows that he/she will not gain or benefit from the fraudulent/ethical behavior of organizational actors.

However, there are situations where the potential whistle-blower may prefer to remain silent for various reasons. The decision of potential whistle-blowers to remain silent even where there are persuasive red flags of fraud is organizations is not surprising for obvious reasons. One, employees who have a fiduciary duty of care and loyalty to their organization may have weak incentives to blow the whistle and would rather prefer to remain silent or risk losing their jobs due to disloyalty to the organization (Vera-Munoz, 2005). Two, individuals and employees will prefer to remain silent when there are obvious fraud red flags if anonymous reporting is not permissible within the organization. Today, many modern organizations in advanced and primitive economies have very little scope for anonymous reporting, which partly explains why there are few whistle-blowers. Three, employees in firms that have a history of providing little or no support to whistle-blowers are more likely to remain silent even in the presence of obvious red flags of fraud. Four, potential whistler-blowers in organizations can choose to remain silent about persuasive fraud red flags when they feel that the organization has a specialized internal audit and control unit, and expect the internal audit and control unit to detect those fraud red flags themselves.

Financial incentive to whistle-blowers is another source of motivation to encourage whistle-blowing. The impact of financial incentives on whistle-blowing to an internal or external authority is not clearly understood in the literature (Pope and Lee, 2013). For instance, Dyck et al (2010), after examining accounting and non-accounting fraud cases in the US during the 1996 to 2004 period, conclude that monetary incentives for fraud revelation appear to play a role in corporate whistle-blowing. Feldman and Lobel (2010) find a significant association between financial incentives and the perceived severity of organizational misconduct. However, they observe that those who view the misconduct to be less-severe were likely to be influenced by financial incentives to report the misconduct. Andon et al (2016) investigate whether the provision of financial incentives and the perceived seriousness of the wrongdoing encourage whistle-blowers to blow the whistle to a relevant external authority. They took an experiment involving professional accountants as participants, and find that the perceived seriousness of the wrongdoing leads to greater intention to blow the whistle to a relevant external authority regardless of the presence of a financial incentive. However, they observe that the presence of a financial incentive increases the intention to blow the whistle even when the perceived seriousness of the financial reporting fraud is low. While an understanding of the effectiveness of financial incentives in promoting whistle-blowing is important, it is needful to apply caution when advocating for financial incentives to whistle-blowers because the provision of financial incentives to whistle-blowers can lead to two effects. On the positive side, financial incentives can encourage whistleblowers to report financial reporting fraud when there are available financial incentives. On the negative side, the presence of financial incentives can lead to fraud-hunting against managers by potential whistle-blowers (or employees) in the sense that any financial reporting irregularity might be reported as fraud when it is not fraud in some cases.

${ }^{2}$ King III (1999) suggests that an organization's structure can play a significant role in the decision to report versus not report wrongdoing. 


\section{Conservatism and Whistle-blowing}

Conservatism in whistle-blowing occur when the potential whistle-blower undertakes some degree of verification to determine whether fraud red flags are actual fraud, and to determine the intent for committing fraud before reporting the fraudulent act. Conservatism in whistle-blowing helps the whistle-blower to ascertain whether there is an underlying moral intent behind the fraudulent act even though the act is clearly fraudulent, illegal, unethical, unfair or misleading to others, the community and society. The information obtained by the potential whistle-blower during the verification process will help the potential whistle-blower make a decision on whether to blow the whistle or to remain silent. If the potential whistle-blower proceeds to blow the whistle after obtaining some verification, such individual/employee/company is referred to as a conservative whistle-blower. On the other hand, an aggressive whistle-blower is an individual or organization that do not obtain any form of verification about fraud red flags and the intent behind fraudulent behavior before reporting to the relevant authority. It is important to stress at this point that conservative whistle-blowing is not the same as the fear of blowing the whistle. Rather, conservative whistle-blowing is an attempt to avoid making false fraud allegations by obtaining some understanding or information about the intent behind fraudulent/unethical behavior which in turn helps the potential whistle-blower to decide whether to blow the whistle or to remain silent in certain situations.

Let's take the case of a bank as a good example. Consider the case of a potential whistle-blower, who is also a bank employee, who is 'aware' and 'understand' that the bank intend to use accounting techniques to manipulate profit in order to artificially increase the level of profit in the short term because the bank realized substantial losses due to massive loan defaults arising from bad economic conditions. If the employee blow the whistle against this manipulation of bank profit without having prior knowledge of the circumstance that led the bank to engage in such behavior, then the employee is an aggressive whistle-blower. On the other hand, the employee is less likely to blow the whistle if he/she understand that the fraudulent behavior (i.e. profit manipulation) of the bank during that period is to ensure that the bank remain a going concern in the short term in the face of massive losses that threatens the bank's survival during bad economic periods. However, if the employee has this knowledge and still proceeds to blow the whistle, then the employee is a conservative whistle-blower.

If the potential whistle-blower (or bank employee) feel that all fraud red flags points to actual fraud, the employee will blow the whistle without engaging in any verification process. When this is the case, the employee is an aggressive whistle blower. On the other hand, if the potential whistle-blower (or bank employee) understand that not all fraud red flags points to actual fraud, the employee will engage in some verification activity before blowing the whistle, thus, making such employee a conservative whistle-blower. In either case, I reiterate that conservative whistle-blowing is not the same as the fear of blowing the whistle, rather it is an attempt by the potential whistle-blower to understand whether fraud red flags points to actual fraud or whether they point to justifiable financial and non-financial irregularities.

While conservatism in whistle-blowing may be criticized because it delays the reporting of fraud red flags and also discourages potential whistle-blowers from reporting fraud if they find an underlying moral intent to justify the fraud, however, the verification required in conservative whistle-blowing is rather intended to reduce the risk of whistle-blowers becoming targets and victims of their own actions especially when whistle-blowers report false red flags of fraud and also when they do not take into account the context that leads to unethical or fraudulent behavior. Furthermore, aggressive whistle-blowing in public corporations is rare because employees in public corporations, while serving public interest, have a duty to preserve the integrity of the local, state or federal government which the public corporation represents (Brewer and Selden, 1998; Lavena, 2016). In this sense, conservative whistle-blowing is likely to be more common in public corporations because employees in public corporations understand what constitute actual fraud, and are more privy to private information in public corporations to ascertain whether financial and non-financial reporting irregularities constitute fraud. Employees' access to private information in public corporations and the need to preserve the integrity of the local, state or federal government which the public corporation represents combine together to encourage more conservative whistle-blowing in public corporations, which in most cases leads to no incidence of whistle-blowing in many public corporations. On the other hand, potential whistle-blowers in private companies are less privy to private information that could help them verify whether fraud red flags points to actual fraud. Hence, there will be less conservative whistleblowing in private companies. The relative lack of access to private information by employees or potential whistle blowers in private companies makes it difficult for potential whistle-blowers to obtain information to understand the intent behind any observed unethical or fraudulent practice, thus, providing little scope to verify fraud red flags. In this sense, whistleblowers in private firms tend to be aggressive whistle-blowers. In a nutshell, conservatism plays an important role in whistle-blowing. 


\subsection{Institutional Influence on Conservative Whistle Blowing}

\subsubsection{Legal/Judicial System}

The quality of a country's legal/judicial system can provide strong incentive or disincentive to blow the whistle against unethical and fraudulent practices in organizations. Potential whistle-blowers in environments with strong (or high quality) legal systems are more likely to blow the whistle because they trust the judicial system to hold fraudsters accountable. In this sense, countries with strong legal/judicial system should have more incidence of whistle-blowing compared to countries or environments with weak (or low quality) legal/judicial systems. On the other hand, a strong legal/judicial system could also increase the litigation cost that whistle-blowers might face if they report false fraud red flags. If fraud red flags are false, the accused person(s) or organizations can file libel charges and other compensation against the whistle-blower. For this reason, potential whistle-blowers in environments with strong legal systems will be cautious and engage in conservative whistle-blowing activities in order to avoid litigation risks and related consequences arising from falsely blowing the whistle against suspected fraud red flags that aren't true. In this sense, conservative whistle-blowing can be expected in countries with strong legal/judicial systems.

\subsubsection{Securities Law}

In securities market, existing securities laws can also influence conservatism in whistle-blowing. While it is true that the nature, structure and efficacy of securities laws vary widely across countries (La Porta et al, 2003), securities law are put in place to elicit good behavior from the issuers and users of capital in financial markets. Normally, securities law should lower the cost of private contracting by standardizing securities contracts, and should clarify liability rules to prevent false and misleading disclosures to investors. However, securities law by itself cannot elicit good behavior from securities market participants without an enforcer, hence, the need for a securities law enforcer like the SEC. Securities law enforcers ensure that corporate disclosures to investors are reliable and relevant for decision making by investor. In principle, the securities law enforcer (i) should be free from political interference, (ii) should be able to commit additional resources to verify corporate disclosures, and (iii) should have investigative powers and should be able to impose noncriminal and criminal sanctions on fraudulent behavior in securities markets. When this is the case, countries with a strong securities law enforcer will have a regulatory environment that discourage fraudulent behavior among securities market participants which in turn creates an environment that encourage aggressive whistle-blowing rather than conservative whistle-blowing because potential whistle-blowers can quickly report fraud red flags to the enforcer while allowing the securities law enforcer to bear the responsibility for verifying fraud allegations made to it by whistle-blowers. The presence of a strong securities market enforcer will reduce the incentive for whistle-blowers to verify whether fraud red flags point to actual fraud. Therefore, one would expect less conservative (i.e., more aggressive) whistle-blowing in countries with a securities law enforcer that have substantial verification, investigative and prosecutorial powers. For example, the US and UK SEC have substantial verification, investigative and prosecutorial powers. Conversely, conservatism in whistle-blowing is expected to be pronounced in environments with no securities law enforcer and in environments where the securities law enforcer has weak verification, investigative and prosecutorial powers because potential whistle-blowers will have to bear much of the responsibility to prove that their allegations for suspected fraud red flags are true. Also, in the absence of a securities law enforcer, there will be greater demand for verifiable information in securities and financial markets, and fraud allegations made by whistle-blowers might not be taken seriously due to doubt about whether such allegations are true. In this case, whistle-blowers in listed companies are more likely to be conservative in their whistle-blowing activities.

\section{Politics and Whistle Blowing}

Politics also play a significant role in the outcome of whistle-blowing that take place in politically-connected firms. Politics or political intervention in the aftermath of whistle-blowing often give rise to conflict of interest between whistle-blowers, managers, firm owners and politicians connected to the firm. If the management of politically-connected firms have the full support of firm owners and politicians connected to the firm, whistle-blowing against top-management fraud may not yield the intended outcomes expected by corporate whistle-blowers. In fact, while whistle-blowers may be satisfied that they have fulfilled their moral responsibility to expose falsehood at any corporate level, politicians connected to the firm can become angry because their political ambitions may be at risk due to fraud revelation of firms they are affiliated with. 
Also, firm owners may become angry with whistle-blowers because of the loss of firm reputation due to fraud-related whistle blowing. Taken together, the political ambitions of politicians connected to the firm, the reputation concerns of firm owners and the career concerns of top management of the firm often combine to produce specific actions or reactions that either (i) compel top management to accept the fraud allegation(s) and discipline the fraudster in politically connected firms; or (ii) may produce specific actions that downplay fraud allegations made by whistle-blowers in politically-connected firms. If an employee blows the whistle to an external body or industry regulator, the management of the firm and politicians connected to the firm can team up to lobby the legal and judicial process in order to drop the fraud allegation made against the firm, and the way such lobbying play out will differ across firms in several countries. The main point here is that the lobby activities of politically-connected firms backed by political incentives can play a significant role on the outcome of whistle-blowing against fraud in politically-connected firms.

However, the extent to which politically-connected firms can take actions to either thoroughly investigate or discipline fraudsters or to lobby the legal and judicial process to drop fraud allegations against it will depend on the strength of a country's political economy and its institutions. By political economy, I mean the political process through which decisions are made by self-interested agents/politicians responding to political incentives to either protect their selfinterests or to improve the fight against corruption to ensure greater accountability in the public and private sector (Kaufman et al, 2011). ${ }^{3}$ Because the strength of a country's political economy is strongly articulated by the enforcement quality of its political economy institutions responsible to fight corruption and improve accountability levels, politicallyconnected firms in countries with strong political economy institutions will face more pressure to respond appropriately when fraudulent behavior in politically-connected firms is reported to external regulators. Politically-connected firms will face more pressure to act ethically to investigate reported fraud allegations, identify the fraudster(s) and discipline the fraudster(s) if the fraud allegation(s) made by whistle-blowing are true. On the other hand, a weak political economy environment create opportunities for politically-connected firms to downplay and deny claims made by external (or internal) whistle-blowing especially when the existing political economy and its institutions do not effectively tackle the issue corruption and accountability in the public and private sector. In such environments, potential whistle-blowers tend to have weak incentives to blow the whistle to report fraud for fear of being targets and victims of their own actions. In such countries, the incidence of whistle blowing tends to be very low even in a decade or more. Overall, the propensity for politically-connected firms to take fraud allegations seriously will be greater when they are in countries/environments with strong political economy (comprising of political economy institutions that strongly discourage corruption and require accountability in the public and private sector).

Following the reasoning above, it is easy to understand how politics can interfere with whistle-blowing and a classic example that comes to mind is the case of Edward Snowden versus the US Central Intelligence Agency (CIA). In 2013, Edward Snowden blew the whistle against the CIA Corporation in the US. Documents leaked by Snowden revealed how the US spy program monitored the mobile phone communications of the US population and other foreign leaders without their consent. Snowden leaked the document because he was concerned that the CIA's actions were unethical, illegal and unconstitutional at that time, and he felt it was his moral obligation to expose and report falsehood. In response, the US government responded and downplayed Snowden's allegations by bringing legal charges of espionage against the whistle-blower - Edward Snowden (see, Wu et al, 2015 for more on this). The case of Edward Snowden shows how whistle-blowing outcomes can be altered through firm-level politics and political economy at country-level which is also driven by economic and/or political incentives.

\section{Firm Ownership Control and Whistle Blowing}

Corporate governance of firms can be viewed either in terms of the agency conflict between managers versus firms owners (Klein, 2002; Park and Shin, 2004), or in terms of the shared benefit of control versus private benefit of control in firms (Aghion and Bolton, 1992; Shleifer and Wolfenzon, 2002). This section focus on the latter. In firms where the conflict of interest is centered on controlling shareholders versus non-controlling shareholders, the incentive to blow the whistle against corporate fraud may be influenced by ownership control. In firms with large number of controlling/majority shareholders, potential whistle-blowers may have weak incentives to blow the whistle if they perceive that controlling/majority shareholders extract substantial amount of private benefits of control and reward managers in return

${ }^{3}$ Clearly, there are substantial political economy differences across countries around the world and these differences may be correlated with corporate governance mechanisms in each country (Kaufman et al, 2011). 
by protecting the career interest of managers in the firm. If the management team have the full support of controlling shareholders who receive private control benefits from managers ${ }^{4}$, controlling/majority shareholders can pressure board of directors to defend the career interest of accused managers if the manager is the accused fraudster following any incidence of fraud-related whistle-blowing, particularly, if the whistle-blowing is made within the organization. Controlling shareholders can use their influence to pressure the board of directors to resolve the fraud allegation internally within the organization without firing the accused individual(s) especially if the accused individual(s) are personally related to controlling shareholders. In some situations, controlling shareholders may immediately or later recommend the dismissal of the whistle-blower with a reward of severance payment. On the other hand, if a firm has a more disperse ownership structure, potential whistle-blowers may have stronger incentives to blow the whistle against fraud if they perceive that a coalition of minority (or non-controlling) shareholders can team up to pressure the board to fire the accused fraudster from the firm if their vote can outweigh the vote of the opposing coalition of shareholders that want to protect the career concern of the accused individuals (or accused manager).

In reality, shareholders with similar interests in widely-held firms tend to form coalition groups to pressure the board to pursue their interests. Since no single shareholder can significantly influence the decisions of the board of directors in firms that are widely held, potential whistle-blowers tend to be more optimistic about the outcome of their whistle-blowing intentions with the hope that a coalition of shareholders will successfully pressure the board of directors to take disciplinary actions against the fraud perpetrator, including the need to fire the accused individual(s). However, if the opposing coalition-shareholder group succeed to persuade the board to take action against fraud but not to fire the accused individuals, the whistle-blower is to likely face retaliation in the near future and may be dismissed from the firm because of the reputation cost to the company arising from such whistle-blowing. Overall, this suggests that even if a company has a unit/department that deals with whistle-blowing and fraud-related issues, the ownership control of the firm can have a significant influence on the outcome of whistle-blowing activities in firms and can affect the career prospects of the whistle-blower in the firm they belong to.

\section{Conclusion}

Whistle-blowing is important to fraud detection activities. Whistle-blowing can help regulators and firms to save substantial resources that would otherwise go into fraud investigation if whistle-blowers emerge early enough and quite often. The tradeoff between the cost and benefit of whistle-blowing may compel the whistle-blower to apply some degree of conservatism in their whistle-blowing activities. Also, politics at firm-level and country-level may also influence the whistle-blowing culture in a country at a particular time. Despite the provision of financial incentive to blow the whistle, whistle-blowers that take into account the larger context of the whistle-blowing environment may find weaker or stronger incentives to blow the whistle. Furthermore, we show that the incentive to blow the whistle can be influenced by the ownership control between controlling and non-controlling shareholders. Finally, this study provides some theoretical explanations on the influence of conservatism, politics and ownership control on whistle-blowing. The limitation of the study is the lack of data to empirically test the argument in this paper. This limitation also create opportunities for future studies to empirically examine the influence of conservatism, political economy and ownership control on whistle-blowing.

\section{Reference}

ACFE. (2016). Report to the Nations on Occupational Fraud and Abuse: 2016 Global Fraud Study, Association of Certified Fraud Examiners.

Andon, P., Free, C., Jidin, R., Monroe, G. S., \& Turner, M. J. (2016). The Impact of Financial Incentives and Perceptions of Seriousness on Whistleblowing Intention. Journal of Business Ethics, 1-14.

Aghion, P., \& Bolton, P. (1992). An incomplete contracts approach to financial contracting. The review of economic Studies, 59(3), 473494.

Barnett, T., Bass, K. \& Brown, G. (1996). Religiosity, ethical ideology, and intentions to report a peer's wrongdoing. Journal of Business Ethics, 15(11), 1161-1174.

Brewer, G. A., \& Selden, C. S. (1998). Whistle blowers in the federal civil service: New evidence of the public service ethic. Journal of Public Administration Research and Theory, 3, 413-439.

${ }^{4}$ If controlling shareholders do not like or support the current management team, they can influence the board of directors to appoint a new management team. Hence, in practice, top management will tend to seek the support of controlling shareholders. 
Curtis, M. B., Conover, T. L. \& Chui, L. C. (2012). A cross-cultural study of the influence of country of origin, justice, power distance, and gender on ethical decision making. Journal of International Accounting Research, 11(1), 5-34.

Dyck, A., Morse, A., \& Zingales, L. (2010). Who blows the whistle on corporate fraud? The Journal of Finance, 65(6), $2213-2253$.

Feldman, Y., \& Lobel, O. (2010). The incentives matrix: The comparative effectiveness of rewards, liabilities, duties, and protections for reporting illegality. Texas Law Review, 88(6), 1151-1211.

Hooks, K.L., Kaplan, S.E. and Schultz, J.J. Jr (1994), Enhancing communication to assist in fraud prevention and detection, Auditing: A Journal of Practice and Theory, 13(2), 86-117.

Kaufmann, D., Kraay, A., \& Mastruzzi, M. (2011). The worldwide governance indicators: methodology and analytical issues. Hague Journal on the Rule of Law, 3(02), 220-246.

King III, G. (1999). The implications of an organization's structure on whistleblowing. Journal of Business Ethics, 20(4), 315-326.

Klein, A. (2002). Audit committee, board of director characteristics, and earnings management. Journal of accounting and economics, 33(3), 375-400.

LaPorta, R., Lopez-de-Silane, F., Pop-Eleches, C., \& Shleifer, A. (2003). Judicial checks and balances, No. w9775. National Bureau of Economic Research.

Lavena, C. F. (2016). Whistle-blowing individual and organizational determinants of the decision to report wrongdoing in the federal government. The American Review of Public Administration, 46(1), 113-136.

Liyanarachchi, G. \& Newdick, C. (2009). The impact of moral reasoning and retaliation on whistle-blowing: New Zealand evidence. Journal of Business Ethics, 89(1), 37-57.

Near, J. P., \& Miceli, M. P. (1985). Organizational dissidence: The case of whistle-blowing. Journal of Business Ethics, 4(1), 1-16.

Ozili, P. K. (2015). Forensic Accounting and Fraud: A Review of Literature and Policy Implications. International Journal of Accounting and Economics Studies 3 (1), 63-68

Park, Y. W., \& Shin, H. H. (2004). Board composition and earnings management in Canada. Journal of corporate Finance, 10(3), 431457.

Park, H., Blenkinsopp, J., \& Park, M. (2014). The influence of an observer's value orientation and personality type on attitudes toward whistleblowing. Journal of business ethics, 120(1), 121-129.

Ponemon, L.A. (1994), "Comments - whistleblowing as an internal control mechanism: individual and organizational considerations", Auditing: A Journal of Practice and Theory, 118-130.

Pope, K. R., \& Lee, C. C. (2013). Could the Dodd-Frank Wall Street Reform and Consumer Protection Act of 2010 be helpful in reforming corporate America? An investigation on financial bounties and whistle-blowing behaviors in the private sector. Journal of business ethics, 112(4), 597-607.

Read, W. J., \& Rama, D. V. (2003). Whistle-blowing to internal auditors. Managerial Auditing Journal, 18(5), 354-362.

Shleifer, A., \& Wolfenzon, D. (2002). Investor protection and equity markets. Journal of Financial Economics, 66(1), 3-27.

Vera-Munoz, S. C. (2005). Corporate governance reforms: Redefined expectations of audit committee responsibilities and effectiveness. Journal of Business Ethics, 62(2), 115-127.

Westin, F. (1982).Whistle blowing. New York: McGraw-Hill.

Wu, A., Ma, W. W., \& Chan, W. W. (2015). Whistleblower or Leaker?" Examining the Portrayal and Characterization of Edward Snowden in USA, UK, and HK Posts. In New Media, Knowledge Practices and Multiliteracies, p. 53-66. Springer Singapore. 